\title{
Kent Ağaçlarının İşlevleri, Koruma Önemi ve Değer Belirleme Yaklaşımları

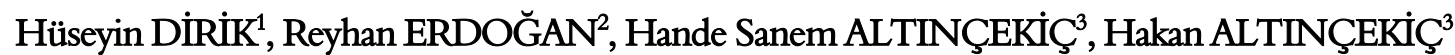

${ }^{1}$ Istanbul Üniversitesi Orman Fakültesi Orman Mühendisliği Bölümü, İstanbul

${ }^{2}$ Akdeniz Üniversitesi Ziraat Fakültesi Peyzaj Mimarlığ Bölümü, Antalya

${ }^{3}$ Istanbul Üniversitesi Orman Fakültesi Peyzaj Mimarlığı Bölümü, İstanbul

\section{Eser Bilgisi:}

Derleme

Sorumlu yazar: Reyhan ERDOĞAN, e-mail: reyhanerdogan@akdeniz.edu.tr

doi: http://dx.doi.org/10.17474/acuofd. 74718

\section{ÖZET}

Kentsel ekosistem içinde kent ağaçlarının önemli bir yeri vardır. Hızla kentleşen ülkemizde yeşil alanların kentin yeni ihtiyaçlarına cevap verebilmek için farklı kullanım alanlarına dönüştüğü kentlerimizde ağaçlar, yerel yönetimlerin ve kentlilerin üzerinde daha fazla hassasiyet göstermesi gereken bir durum kazanmıştır. Bu konuda bilimsel bilginin yanında, ciddi uygulama tekniklerini de gerektiren duyarlı yaklaşımlara ihtiyaç duyulmaktadır. Kent ağaçları konusunda daha önce yapılan çalışmalara bakıldığında ağaçların dendrolojik özellikleri ve işlevleri konusunda çok fazla bilgi birikimi olmasına rağmen, koruma ve değer belirleme konularının yeterince ele alınmadığı ve yeterli bilginin olmadığı görülmektedir. Bu makalede, kent ağaçlarının işlevleri, koruma ve değer belirleme yaklaşımlarında kullanılabilecek mevcut literatürlere ek niteliğinde yazarların uygulamalarla geçerliliğini deneyimledikleri formüller ve yaklaşımlar sunulmuştur.

Anahtar Kelimeler: Kent ağaçları, işlev, koruma, değer belirleme

\section{Functions, Conservation Importance and Value Assignment Approaches of Urban Trees}

\section{Article Info:}

Review

Corresponding author: Reyhan ERDOĞAN, e-mail: reyhanerdogan@akdeniz.edu.tr

\section{ABSTRACT}

Urban trees are very important for the urban ecosystem. Local governments and the citizens should show more sensitivity towards them, because green areas of the city are rapidly transformed into concrete in our country in order to meet the new needs of our cities. It is needed a serious application techniques beside to scientific knowledge on this subject into different areas of trees. There is lots of knowledge on functional and dendrological properties in the previous studies on urban trees, however there is lack of information about protection and valuation issues. In this article, in addition to the existing literature, some approaches and formulas that the authors experimented to the validity of applications are presented on value, benefits and costs of urban trees.

Keywords: Urban trees, function, protection, determine of value

\section{GiRiş}

Doğal hayatın destek sistemini oluşturan ağaçlar (Kuchelmeister 2000), kentsel yaşamın sürdürülebilir olmasında da oldukça etkin rollere sahiptir. Aynı zamanda ağaçlar, estetik, ekolojik, psikolojik, hijyenik ve işlevsel kapsamlı çok yönlü yararları ile son yıllarda kentsel yaşam kalitesi düzeyinin ortaya 
konmasında belirleyici bir element olarak kabul edilmektedir. Bu nedenle kentlerde ağaç kültürü, yerel yönetimlerin başlıca faaliyet konularından birini oluşturmaktadir.

Söz konusu yararlar, kentsel peyzaj düzenlemelerindeki bitkilendirmelerin reel ve ir reel değerlerini yansitır. Ağaç yetiştirmenin reel değeri, tesis aşamasından itibaren belirli bir zaman dilimine kadar yapilan parasal harcamalarla ortaya konmaktadır. Ancak ağaçların o ana kadar gerçekleştirdiği estetik, ekolojik, sosyo kültürel, psikolojik, hijyenik ve işlevsel kapsamlı ir reel değerleri, tesis ve bakım masraflarından daha büyük ve önemlidir. Bazı yaklaşımlarla sayısal olarak ortaya konabilen bu değerler, aynı zamanda kentsel ağaç kültürünün amaçlarının da bir göstergesidir (Dirik 2014).

$\mathrm{Bu}$ çalışmada kent ağaçlarının kent içindeki işlevleri, koruma önemleri ve değer belirleme yaklaşımları ortaya konularak, kentsel mekânlardaki ağaç varlığı ile ilgili değer yargılarına katkı sağlamak amaçlanmıştır.

\section{Kent Ağaçlarının İşlevleri ve Değerleri}

Kent ağaçları sosyo-kültürel, estetik, süsleyici, psikolojik, ekolojik ve parasal olmak üzere çok yönlü işlevlere sahiptir. Ağaçlar sahip oldukları işlevlere göre değerlendirilmektedir.

\section{Sosyo-kültürel Değerleri}

Ağaçlar geçmişten günümüze değin bir kült simgesi olarak kabul edilmiştir. Antik Yunan çağından modern çağa kadar hayatın devamlılığının ve kozmik gücün simgesi olarak algılanmış ve bu bağlamda duyulan sayg1, kesintisiz devam etmiştir (Pardo 2005). Güzellik, cesaret, direnç ve yaşamın temel gücü olarak görülmesi evrensel bir değer olarak paylaşılmıştır (Musselman 2003; Albian ve Berwick 2004). Çeşitli toplumlar ağaçlardan büyülü totemler yaratmışlardır. Bazı özel nitelikli ağaçlar, "azizlik" ve "peygamberlik" sıfatları ile kutsallaştırılmıştır (Séne 2003). Alman şair Goethe, Strasburg Katedralini hem organik ve canlı yapısı, hem de üzerinde taşıdığı milyonlarca ince detaya karşın görünümündeki etkileyici bütünlük ve uyum nedeniyle "tanrı ağacı" ya da "kutsal ağaç" olarak tasvir etmiştir. Ayrıca, gotik sanatı ile kutsal ağaç arasında özel ve ayrıcalıklı bir yakınlık ya da benzerlik olduğundan bahsetmiştir (Krulic 2004).

Bazı medeniyetlerde, yazılarda kullanılan harfler ağaçlardan seçilmiştir. Baltık alfabesinin (Ogham) 25 karakteri, 20 ağaç ve bazı kutsal bitkilerden oluşur. İrlanda kültüründe de kayın ağacının odunundan eski yazı takımlarının yapımında yararlanılmış, ağacın ince kabukları da ilk kitapların sayfaları olarak kullanılmıştır. Nitekim İngilizce ve diğer bazı Hint Avrupa dillerinde kitap (book) kelimesi ile kayın kelimesi (beech) etimolojik olarak birbirine bağlıdır (Crews 2003).

Ağaçlar ve ormanlarla ilgili tabu, ayin ve inançlarla desteklenen ve kuşaktan kuşağa aktarılan mistik folklor, dinler ve geleneklerdeki ağaç sevgisinin temelini oluşturmaktadır (Swamy ve ark. 2003; Garcia ve ark. 2006). İncil'de ağaç ve ormana yapılan atıf sayısı 525'tir. Bu, insandan sonra tüm canlı varlıklar içindeki en yüksek atıf sayısıdır (Musselman 2003). İslam dininde ağaç sevgisine büyük önem verilmiştir. Kur'an-1 Kerim'in en az 50 ayetinde doğanın araştırılması önerilmektedir. İslam'da doğanın araştırılması ibadete eşdeğer sayılmıştır (Tez 2008).

Yukarıda kısaca değinilen hususlar ağaçların tarih boyunca insan ve toplum ölçeğinde sosyo-kültürel ve folklorik 
açılardan taşıdığı önemi açıkça ortaya koymakta ve toplumsal yaşamin vazgeçilmez bir bileşeni olduğunu göstermektedir.

\section{Estetik ya da Süsleyici Değerleri}

Ağaçlar, estetik açıdan kent ortamındaki yapıların katı ve keskin hatlı oluşumlarını yumuşatır, kontrast şekil ve tekstürler oluşturarak ilginç ve etkileyici görünümler yaratır. Soliter durumda odak noktası ve vurgu oluşturarak dekoratif görünümler sergiler. Özellikle cadde ve bulvarlarda tesis edilen allelerle derinlik fikri vererek, ölçek ve perspektif görünümler yaratırlar. Ağaçlar diğer bitkilerle birlikte, bir peyzajı çevreleyerek veya bir objeyi kuşatarak görsel çerçeve oluşturmaktadırlar. Obje veya mekânları biri birine bağlarken, fon ve görsel siluetler sergilerler. Ayrıca, mekân yaratma özellikleri ile mekânlara anlam ve nitelik kazandırırlar. Topografik yapıyı güçlendirirler. Sınırlama ve siperleme etkileri ile görünümü arzu edilmeyen yerlerin ve bazı özel mekânların gizlenmesini sağlarlar.

Ağaçlar asırlardan beri sahip oldukları güzellikleri ile şairlere, sanatçılara ve yazarlara ilham kaynağı olmuşlardır. Şair William Wordsworth'un "Borrowdale Yews"i ve romantik peyzaj ressamı John Constable'in "La charrette de foin (saman arabası)" bunun en güzel örneklerinden biridir (Russel ve Culter 2008).

\section{Psikolojik Değerleri}

Ağaçlar sürdürülebilir kent yaşamında diğer işlevleri ile birlikte toplumunun psikolojik ve sosyo-kültürel gereksinimlerini karş1layan en önemli elementlerdir (Konijnendijk ve ark. 2004). Kentsel bitki varlığı her şeyden önce insanlara kent ortamında doğa ile temas etme ve mevsimlerle doğada oluşan değişimleri gözlemleme olanağı vererek doğa ile bütünleşmelerini sağlarlar. Doğadan kopuk büyük kentlerde yaşayan insanlarda konsantrasyon kayıpları, saldırganlık, ruhsal çöküntü gibi psikolojik rahatsızlıklar belirgin düzeyde yüksektir. Birçok araştırma, doğal alanlarda dolaşmanın ve konaklamanın, dolaşım ve sinir sistemleri ile ilgili çeşitli rahatsızlıkları iyileştirebildiğini ortaya koymuştur (Çolak 2001, Westphal 2003). Yapılan bir araştırmada, ameliyat sonrasındaki bakım sürecini penceresi parka bakan bir hastane odasında geçiren hastaların iyileşme sürelerinin $\% \quad 10$ oranında kısaldığı saptanmıştır (Vergriete ve Labrecque 2007).

\section{Ekolojik ve İşlevsel Değerleri}

Doğal hayatın destek sistemini oluşturan ağaçlar ve bitkiler; iklimi kontrolü, havayı arıtma, karbon birikimini azaltma, toprak ve su dengesini koruma, su verimi ve kalitesini artırma, gürültü, toz, gaz ve rüzgar zararlarını önleme işlevleri ile bulundukları ortamları yaşanabilir çevrelere dönüştürürler.

Ağaçlar, 1sı adasına dönüşen kentlerde siper oluşturma, perdeleme ve gölgeleme etkileri ile iklimi dengeleyip, uç değerleri azaltırlar. Kent içi iklim koşullarının yumuşatılması, aynı zamanda yazın soğutma, kışın da isıtmada kullanılan enerji harcamalarının azalmasına, böylece fosil yakıt kullanımından kaynaklanan hava kirliliği oranının düşürülmesine katkı sağlar (Dirik ve Ata 2005).

Ağaçlar $\mathrm{CO}_{2}{ }^{\prime} \mathrm{i}$ tüketerek $\mathrm{C}$ birikimi, küresel 1 sınma ve yağış rejiminin bozulması gibi tehlikeleri azaltırlar; $\mathrm{O}_{2}$ üreterek kent havasının doğal arıtımını gerçekleştirirler. 0.4 ha büyüklüğündeki ağaçlı bir alan her gün 18 kişinin yaşamak için gereksinim duyduğu $\mathrm{O}_{2}{ }^{\circ} \mathrm{i}$ üretir (Russel ve Culter 2008). Kent havasındaki $\mathrm{CO}_{2}$ 'in azaltılmasında kent ağaçlarının 
etkinliği çevre ormanlarına göre 10 kat daha fazladir (World Forestry Center ve Morgan 2005). Başka bir çalışma, ağırlığ 1,5 tona ulaşan gelişmiş haldeki yaşlı ve sağlıklı bir meşe ağacinın 0,5 ton $\mathrm{C}$ tuttuğunu ortaya koymuştur (Forrest 2006). Yapilan hesaplamalarla olgun yaştaki bir ağacın yılda $20 \mathrm{~kg}$ tozu yakalayıp toprağa mal ettiği saptanmıştır. Tozlar yanında ozon, klor, flor, kükürt dioksit ve PAN (peroksi asetil nitrat, dumanlı sisin fotokimyasal bileşeni) gibi kirletici gazların hepsi ağaçlar tarafindan emilebilmekte, partiküller de etkili bir şekilde tutulabilmektedir (Harris ve ark. 2004).

Ağaçların gürültünün yayılmasındaki engelleyici işlevleri iyi bilinen bir konudur. Ağaçlara çarpan ses titreşim dalgaları ve sonor enerji, belli ölçülerde dallar ve yapraklar tarafindan yansitılır ve absorbe edilir. $30 \mathrm{~m}$ genişlikteki ağaçlı bir kuşak gürültü kirliliğini 6 ile $8 \mathrm{~dB}$ düzeyinde azaltır (Lamontagne 2008).

Ağaçlar kentteki zararlı hava hareketlerinin kontrol edilmesinde belirgin düzeyde etkili olurlar. ABD'nin Pennsylvania kentinde \%67 düzeyinde ağaçlandırılmış bir caddede ölçülen yerden $2 \mathrm{~m}$ yükseklikteki rüzgâr hızının, ağaçsız bir caddeye göre kışın \%60, yazın da \% 67 oranında azalmış olduğu saptanmıştır (USDA 2005). Ağaçlar kökleri ile toprağı sıkıca kavrayarak erozyonla toprağın aşınma ve taşınmasını engelleyerek, yağışlarla gelen suların toprağa sızmasını kolaylaştırırlar. $\mathrm{Bu}$ yönüyle kentlerdeki yer altı sularının dengesine de katkı sağlarlar. Peyzaj içinde bir kente yaklaşmayı, yol kenarlarında güzergâhın seyrini ve mekân algısını güçlendiren bir sinyal ya da röper işlevi görürler. Ağaçlandırılmış alanlar, kentsel biyolojik çeşitliliğin temeli olup kuşların, birçok hayvanın ve faydalı böceklerin barınması için uygun ortamlar oluşturur. IUCN tarafindan yapilan araştırmalar, kentlerde uygun bir yeşil alan şebekesinin oluşturulmasının, biyolojik çeşitliliğin korunmasına ve geliştirilmesine hizmet ettiğini, yeşil kuşaklar ve lineer parklar gibi yeşil kulvarların, aynı zamanda biyolojik kulvarlara dönüştügüünü ortaya koymuştur (Kuchelmeister 2000).

\section{Parasal Değerleri}

İnsanların ağaç varlığına sahip ortamlarda yaşama istekleri tüm zamanlarda ve her yerde değişmeyen tercihleridir. Kullanıcıların mülk alımlarında ağaçlı alanlara daha yüksek paralar ödemeye gönüllü olmaları ve yaşama ortamlarında ağaçlar ya da bitkiler yetiştirmeleri bu talebin tipik bir göstergesidir.

Emlakçılar, bilirkişiler, inşaatçılar ve kullanıcılar üzerinde yapılan çeşitli anketlerle ulaşılan sonuçlar bu yargıyı net bir şekilde doğrulamaktadır. Harris ve ark. (2004), bu tür anket bulgularına dayanarak ABD'ndeki emlakçıların \%80'inin, ağaçlı evlerin satılabilirliğini ağaçsız evlere göre $\% 20$ oranında daha fazla bulduklarını belirtmektedir. Hartman ve ark. (2000)'a göre ağaç varlığı emlak değerine \%5-20 oranında katkı sağlamaktadır. World Forestry Center ve Morgan (2005) da, çok sayıdaki araştırma bulguları ile bir malikânenin arazisi üzerinde bulunan ağaçlara emlak pazarlamacıları ve kullanıcılar tarafindan \%10 ile 23 arasında değişen değer biçildiğini bildirmektedir. Mevcut bitki varlığı gayrimenkulün değeri ile birlikte vergi matrahını da arttığı için yerel yönetimlerin bu değerin bir kısmını vergi olarak almaları söz konusudur.

Yine bazı araştırmalarda mevcut ağaç varlığının, bulunduğu konuma \%7-15 oranında ekonomik değer kattığı, bu oranın özel durumlarda \%25'e kadar çıktığı belirtilmektedir. Nitelikli bir ağacın yerleşim bölgesindeki bir konutun değerini \%18'e varan oranlarda artırabildiği 
de emlak piyasasının bir ölçüsüdür (Lamontagne 2008).

\section{Kentlerde Ağaç Korumanın Esasları}

Doğal veya dikime dayalı bitki varlığına sahip bir peyzaj düzenleme alanında, gelecek yıllarda bulunduğu yere değer katacak sağlıklı ve sağlam yapılı bitkilerin korunması ile projenin zenginleştirilmesi mümkündür. Başarılı bir "ağaç koruma”, hazırlanacak peyzaj projesinin ana hedeflerinden biridir ve projenin korunacak ağaçlara olası etkilerinin minimize edilmesini gerektirir. Ăgaç korumadaki başarı, uzun dönemde yapısal çalışmalar tamamlandıktan sonra ağacın iyi büyümesi ve gelişmesi ile ölçülür. Akıllıca bir planlama, gösterişsiz bir tasarım uyarlaması ve basit önlemler, mevcut ağaçların korunmasındaki başarıyı arttırır. Ağaç korumanın ana amacı, ağacın planlama alanında uzun süre yaşamasını ve stabilitesini sağlamaktır. Bunu başarabilmek için 3 ana ilkeye uymak zorunludur (Harris ve ark. 2004):

- Ağaç koruma programları, ağacın büyüme ve gelişim modeline uygun olmalıdır. Başarılı bir koruma, bilimsel literatür ve teknik deneyimlerden elde edilen doğru bilgilere dayandırılarak gerçekleştirilebilir.

- Koruma, ağaçlarda yaralanma ve mekanik hasarların önlenmesine odaklanmalıdır.

- Arborikültürel uygulamalar, inşaat çalışmalarının ağaca ya da çevresine verdiği zararları tümüyle onaramaz. Arboristler inşaat faaliyetlerinin neden olduğu spesifik yaralanma veya stresin tedavisinde sinırlı bir etkiye sahiptirler. Ağaçlar inşaat çalışmalarından kaynaklanan zararlara veya ortam değişikliklerine ya uyarlar ya da ölürler.
- Ağaç koruma yeterli boşluk ya da alan gerektirir. Ağaçlar bulundukları ortamda belirli bir alan ve hacim işgal ederler. Ağaç koruma programları, sağlıklı kök sistemi ve tepe taci gelişimine olanak tanımak amacıyla mutlaka dokunulmamış yada etkilenmemiş alan planlamalarını kapsamalıdır. Ayrıca, ağacın büyümesiyle birlikte yaşam alanının yüzey ve hacim olarak giderek artacağı, mutlaka dikkate alınmalıdır.

$\mathrm{Bu}$ ilkeler 1şığında öncelikle planlama alanındaki bitkisel varlığın değerlendirilmesi ile korunması ve çıkarılması gereken ağaçların belirlenmesine yönelik sörvey ve analizlerin gerçekleştirilmesi gerekir. Sörvey çalışmaları ve elde edilen verilerin değerlendirilmesi ile ortaya konan "rölöve veya revizyon planları", aynı zamanda ağaç varlığ ile ilgili "restitüsyon", "restorasyon" ve "renovasyon" projelerinin hazırlanabilmesi için temel altlık oluşturur. Burada adı geçen, ağaç restitüsyonu, sonradan değişikliğe uğramış özgün nitelikli doğal ya da kültürel bir bitki dokusunun, uygun olmayan türlerin uzaklaştırılması, uygun türlerin de yeniden dikilmesi ile yeniden özgün haline getirilmesidir. Ağaç restorasyonu, alanda mevcut olan ve korunması ön görülen hastalıklı, yaralı, çürük, dirençsiz ve zayıf gelişimli ağaçlarda uygulanması gereken yara, kovuk, çürük tedavileri; bağlama, kuşaklama, destekleme önlemleri; havalandırma bacaları, kök yayılış alanının düzenlenmesi, ortam ıslahı, beslenme koşullarının iyileştirilmesi ve patojenlerle mücadele gibi onarım ve geliştirme önlemleridir. Ağaç renovasyonu ise, kötü gelişim, yaşlanma, biyotik ve abiyotik zararlıların etkileri gibi nedenlerle zarar gören ve vital gücünü yitiren mevcut ağaç varlığının yenilenmesine denilmektedir (Dirik 2014). Bu planlar ayrica peyzaj diyagnozu ve tasarım aşamalarında 
düzeltilmiş kotların belirlenmesi, alan hazırlama yöntemleri, ortam sslahı çalışmaları, sirkülasyon, aydınlatma, sulama ve bitkilendirme gibi planlanmalar için de yönlendirici bir rol oynar (Dirik 2008).

Ağaç rölöve ya da revizyon planlarında, alan üzerindeki her bir bitkinin; konumu, türü, boyutları (çap, boy, taç genişliği, dalsız gövde yüksekliği), yapısal özellikleri ve formu (gövde eğriliği, ana çatalların konumu, dallanma ve taç gelişiminin katllı̆̆ğı ve simetrisi vb.), sağllk ve gelişim durumu, yaşı ve olası ömrü, ağaç topluluğu içindeki konumu, komşu ağaçların, yapıların ve yolların neden olduğu baskılardan etkilenme düzeyi, korunmaya, nakledilmeye veya çıkarılmaya uygunluğu, korunması öngörülen ağaçların gerektirdiği bakım ve koruma önlemleri (kök yayılış alanının ıslahı, budama, bağlama, kuşaklama, destekleme, yara tedavisi, kovuk onarımı, parazitlerle mücadele vb.) gibi bilgiler plan, kesit, görünüş ve yazılı metinlerle açıklanmalıdır (Dirik 2008). Bu kapsamda, aşă̆ılda belirtilen yaklaşım ve yöntemler dikkate alınarak öncelikle korunması gereken ağaçlar belirlenmeli ardından da nakledilmesi ve çıkarılması uygun veya gerekli olan ağaçlarla ilgili değerlendirmeler yapılmalıdır.

\section{Ağaçların Koruma Değerinin Saptanması}

Kent ağaçlarının koruma önemi hakkında genel çerçevede bir fikir geliştirmek mümkün olsa da, koruma değerinin somut verilerle tanımlanması sıkça gereksinim duyulan bir konudur. Bununla birlikte koruma değerinin belirlenmesi her koşulda subjektif değerlendirmelere dayandırılmak zorundadır. Zira bir ağacın tür önemi, sağlık durumu, görsel değeri, direnç düzeyi gibi nitelikleri değerlendirmeyi yapan uzmanlara göre farklılık gösterebilir. Söz konusu yetersizlik ve belirsizliklere rağmen bir ağacın koruma değerinin bilimsel temele dayalı yaklaşımlarla belirlenmesi, karar verme çalışmalarına yön verebilen bir öneme sahiptir.

Koruma değeri; yerinde koruma ve alanda koruma şeklinde 2 grupta değerlendirilir. Yerinde koruma, bir ağacın bulunduğu yer ve konumu ile bütünleşik olarak yüksek bir değer taşıması halinde söz konusudur. Alanda koruma ise, yalın halde belli bir değer ifade eden, bununla birlikte taşınması mümkün olabilen ağaçlar için geçerlidir (Dirik 2014).

Ortam değişiklikleri ve kötüleşen zemin koşulları, komşu ağaçların yarattı̆̆ olumsuzluklar, bina ve alt yapı tesislerinin etkileri gibi baskılara maruz kalan ağaçlarda koruma - uzaklaştırma kararının belirlenmesi büyük önem taşır. Bu gibi durumlarda bir ağacin iyi bir performans göstermesi; baskıların toplam şiddeti, tür, yaş ve baskı altında yaşama direnci gibi faktörlere bağlıdır. Tablo 1'deki matris, baskılara karşı dirençli olan Platanus orientalis ile duyarlı olan Magnolia grandiflora türlerinde bir ağacın kalması ya da çıkarılması kararının belirlenebilmesi için yol gösterici bir örnektir (Dirik 2014). 
Tablo 1. Tür toleransı, sağlık durumu ve etki şiddeti dikkate alınarak bir ağacın korunması veya uzaklaştırılması kararının belirlenmesi örneği (Harris ve ark. 2004'den değiştirilerek, Dirik 2014)

\begin{tabular}{|c|c|c|c|}
\hline \multicolumn{4}{|c|}{ Platanus orientalis } \\
\hline \multirow[t]{2}{*}{ Baskının yoğunluğu } & \multicolumn{3}{|c|}{ Ağacın durumu } \\
\hline & Zayıf & Orta & İyi \\
\hline $\mathrm{Az}$ & izle & koru & koru \\
\hline Orta & önlem al, izle & koru & koru \\
\hline Şiddetli & taşı/uzaklaştır & önlem al, izle, koru & önlem al, izle, koru \\
\hline \multicolumn{4}{|c|}{ Magnolia grandiflora } \\
\hline \multirow[t]{2}{*}{ Baskının yoğunluğu } & \multicolumn{3}{|c|}{ Ağacın durumu } \\
\hline & Zayılf & Orta & İyi \\
\hline $\mathrm{Az}$ & izle & koru & koru \\
\hline Orta & taş//uzaklaştır & önlem al, izle & önlem al, izle, koru \\
\hline Şiddetli & taş//uzaklaştır & taşı/uzaklaştır & taşı/uzaklaştır \\
\hline
\end{tabular}

Ağaçların koruma değerini genel çerçevede belirlemek için Kanada'da yapılan bir çalışmada, yukarıda kısaca açıklanan ölçütler formule edilerek değer skalasının çıkarılması yaklaşımı esas alınmıştır. Buna göre ağaç koruma değeri aşağıdaki formül yardımıyla hesaplanmıştır (Arbour 2005);

Ağaç koruma değeri= göğüs yüzeyi $\mathrm{x}$ tür niteliği x mevcut koşulları (sağlık vb.)

Formülde yer verilen parametreler;

- Göğüs yüzeyi= $\pi$ x (1.4 m'deki gövde yar1 çapı)2,

- Tür niteliği; anıtsal nitelik, ömür, büyüme hızı, parazitlere direnç, iklimsel etkilere dayanıklılık, estetik kapasite gibi parametrelere göre \% olarak belirlenmiştir. (Örneğin; Fraxinus pennsylvanica \%80, Ulmus pumila \%50, Acer negundo \%25, Populus nigra var. İtalica \%15),

- Mevcut koşulları; ağaçların fizyolojik ve görsel düzeyi ile yapısal bütünlüğü gibi verilerle saptanmıştır. Düzeyler: iyi: \% 55, orta: \% 40, zayıf: \% 15, kuru: \% 0 ,

olarak ön görülmüştür. Bulunan sonuç koruma değeri olarak kabul edilmiş ve değerlendirme aşağıdaki skalaya göre yapılmıştır.

- 500 puan ve üstü: çok yüksek,

- 250 - 500 puan: yüksek,

- 150 - 249 puan: orta,

- 1 - 149 puan: zayif,

- 0 puan: yok

Aynı ülkede yapılan bir diğer çalışmada da, söz konusu formül ve katsayıları bazı değişiklikler yapılarak uygulanmıştır. Bu yaklaşımda (Cormier 2008);

Ağaç koruma değeri= göğüs yüzeyi $\mathrm{x}$ tür niteliği x mevcut koşulları

Formülde yer verilen parametreler;

- Göğüs yüzeyi= $\pi / 4$ x (1.4 m'deki gövde yarı çapı)2

- Tür niteliği; anıtsal nitelik, ömür, büyüme gücü, parazitlere direnç, iklimsel etkilere dayanıklılık, estetik kapasite gibi parametrelere göre \% olarak belirlenmiştir. (Örneğin; Fraxinus pennsylvanica \%90, Picea pungens \%90, Picea glauca \%80, Thuja occidentalis \%80, Celtis occidentalis $\% 75$, Acer saccharinum \%70, Acer platanoides \%60, Aesculus hippocastanum $\% 60$, Tilia cordata $\% 60$, Tilia americana $\% 60$, Acer rubrum \%55, Ulmus americana 
\%20, Acer negundo \%25, Populus nigra var. İtalica \%15).

- Mevcut koşulları; ağaçların fizyolojik görünümü, estetik değeri ve yapısal bütünlüğü gibi verilerle saptanmıştır. Düzeyler: çok iyi $\% 85$, iyi: $\% 70$, orta: $\% 55$, zayıf: \%20 kuru: \%0 olarak ön görülmüsstür. Bulunan sonuç koruma değeri olarak kabul edilmiş ve değerlendirme aşağıdaki skalaya göre takdir edilmiştir;

- 800 puan ve üstü: çok yüksek,

- 450 - 799 puan: yüksek,

- 175 - 449 puan: orta,

- 1 - 174 puan: zayıf,

- 0 puan: yok

\section{Ağaçların Ekonomik Değerlerinin Saptanmasi}

Ağaçların parasal değerlerinin belirlenmesi $X X$. yüzyılın ilk yarısından itibaren ele alınmış bir konudur. Süreç içerisinde ağaçların reel değerlerinin parasal ölçütlerle tanımlanmasına dönük çok sayıda yöntemler geliştirilmiştir (Cullen 2005). Bir bitkiye basit yaklaşımlar ve genel kurallarla değer biçilmesi mümkündür. Örneğin iyi koşullarda yetişmiş sağlıklı bir ağacın değeri, gövde çapinın her bir inç birimi $(2,54 \mathrm{~cm})$ için $100 \$$ esas alınarak belirlenebilir (City of Portland Bureau of Planning 1999). Bununla birlikte bir ağacin değerinin belirlenmesi, yönteme dayalı hesaplamalarla daha sağlıklı bir şekilde ortaya konabilir.

Ağaçların reel değerinin saptanmasında ülkelere göre değişen farklı yöntemler kullanılmaktadır. Örneğin Fransa'da başta Paris, Lille, Limoges, Marseille, Montpellier, Nantes olmak üzere büyük kentlerde "Ağaç Değeri Tahmini Baremi
(BEVA)", "Helliwell Yöntemi", "Dendropolis Yöntemi", "Quebec Yöntemi”, "EDIF Yöntemi”, “Tesis Masraflarını Esas Alan Yöntem" gibi biri birinden farklı çok sayıda yönteme başvurulmaktadır (Bonnardot ve Riboulet 2004). Bunlardan Fransa'nın birçok kentinde bazı küçük değişikliklerle yaygın olarak kullanılan "Ağaç Değeri Tahmini Baremi (BEVA)" yöntemi aşağıdaki şekilde hesaplanmaktadır (Communauté Urbaine de Lyon 2001):

Ağaç değeri baremi= tür indisi $\mathrm{x}$ konum, estetik, sağlık, güç indisi x büyüklük ya da gövde çevresi indisi

- Tür, varyete indisi: söz konusu taksonun yapraklı türlerde 10/12 çevreye, konifer türlerinde 150/175 cm boya sahip bireyinin fidanlık satış değeridir.

- Konum, estetik değer, sağlık ve vital güç indisi: 1 ile 10 arasında atanan bir değerdir (Tablo 2 ve Tablo 3):

- konum, bulunduğu yere ve soliter, grup, alle ya da sıra gibi bulunuş şekline göre (soliter, 2 - 5 bireyli grup içinde, alle, sıralı bitkilendirmeler ya da 6 dan fazla bireyli grup içinde),

- estetik değer, gövde, tepe tacı ve dallanma şekli ile oluşturduğu görünümüne göre (dikkat çekici, iyi, formu kötü/yaşlı, önemsiz),

- sağlik durumu, gövde dal ve yapraklarda yara, çürük ve patojen mevcudiyetine göre (iyi, orta, kötü),

- vital güç, aynı türün normal koşullarda gelişmiş, sağlıklı bireylerine oranla gösterdiği gelişme gücüne göre (oldukça güçlü, orta düzeyde güçlü, az güçlü, güçsüz). 
Tablo 2. Konum ve estetik değer indisleri (Communauté Urbaine de Lyon 2001)

\begin{tabular}{|l|c|c|c|}
\hline Konum/estetik değer & Soliter & $\begin{array}{c}\text { Grup } \\
\text { 2 -5 birey }\end{array}$ & $\begin{array}{c}\text { Alle, siralı } \\
\text { 6 ve daha fazla birey }\end{array}$ \\
\hline Dikkat çekici & 6 & 5 & 5 \\
\hline İyi & 5 & 4 & 4 \\
\hline Formu kötü/yaşlı & 3 & 2 & 2 \\
\hline Önemsiz & 1 & 1 & 1 \\
\hline
\end{tabular}

Tablo 3. Sağlık durumu ve vital güç indisleri (Communauté Urbaine de Lyon 2001)

\begin{tabular}{|l|c|c|c|c|}
\hline $\begin{array}{c}\text { Sağllk durumu/ } \\
\text { Vital güç }\end{array}$ & Oldukça Güçlü & Orta düzeyde güçlü & $\mathrm{Az}$ güçlü & Güçsüz \\
\hline İyi & 4 & 2 & 1 & 1 \\
\hline Orta & 2 & 2 & 1 & 1 \\
\hline Kötü & 0 & 0 & 1 & 0 \\
\hline
\end{tabular}

- Büyüklük ya da gövde çevresi indisi: Ağacın yaşı ve boyuna göre değer artışını açıklayan ve yerden $1 \mathrm{~m}$. yükseklikten ölçülen gövde çevresi esas alınarak belirlenen değer (Tablo 4),

Tablo 4. Gövde çevresi sınıflarına göre belirlenen büyüklük değeri indisleri (Bourgery ve Bonnardot 2002)

\begin{tabular}{|c|c|c|c|}
\hline \multicolumn{4}{|c|}{ Gövde çevresi sınıflarına göre katsayı değerleri } \\
\hline $10-14 \mathrm{~cm}: 0.5$ & $101-110 \mathrm{~cm}: 9.5$ & $201-220 \mathrm{~cm}: 21$ & $401-420 \mathrm{~cm}: 31$ \\
\hline $15-22 \mathrm{~cm}: 0.8$ & $111-120 \mathrm{~cm}: 11$ & $221-240 \mathrm{~cm}: 22$ & $421-440 \mathrm{~cm}: 32$ \\
\hline $23-30 \mathrm{~cm}: 1$ & $121-130 \mathrm{~cm}: 12.5$ & $241-260 \mathrm{~cm}: 23$ & $441-460 \mathrm{~cm}: 33$ \\
\hline $31-40 \mathrm{~cm}: 1.4$ & $131-140 \mathrm{~cm}: 14$ & $261-280 \mathrm{~cm}: 24$ & $461-480 \mathrm{~cm}: 34$ \\
\hline $41-50 \mathrm{~cm}: 2$ & $141-150 \mathrm{~cm}: 15$ & $281-300 \mathrm{~cm}: 25$ & $481-500 \mathrm{~cm}: 35$ \\
\hline $51-60 \mathrm{~cm}: 2.8$ & $151-160 \mathrm{~cm}: 16$ & $301-320 \mathrm{~cm}: 26$ & $501-600 \mathrm{~cm}: 40$ \\
\hline $61-70 \mathrm{~cm}: 3.8$ & $161-170 \mathrm{~cm}: 17$ & $321-340 \mathrm{~cm}: 27$ & $601-700 \mathrm{~cm}: 45$ \\
\hline $71-80 \mathrm{~cm}: 5$ & $171-180 \mathrm{~cm}: 18$ & $341-360 \mathrm{~cm}: 28$ & \\
\hline $81-90 \mathrm{~cm}: 6.4$ & $181-190 \mathrm{~cm}: 19$ & $361-380 \mathrm{~cm}: 29$ & \\
\hline 91 - $100 \mathrm{~cm}: 8$ & $191-200 \mathrm{~cm} ; 20$ & $381-400 \mathrm{~cm}: 30$ & \\
\hline
\end{tabular}

Alle ağaçlarını esas alan bir diğer hesaplama şeklinde (Bourgery ve Bonnardot 2002);

Bir ağacın konfor ya da finansal değeri= takson indisi $\mathrm{x}$ boyut indisi $\mathrm{x}$ sağlık indisi $\mathrm{x}$ konum ve estetik değer indisi

- Takson indisi: söz konusu taksonun 10/12 çevreye sahip bireyinin fidanlık satış değeri,

- Boyut indisi: Ağacın yaşı ve boyuna göre değer artışını açıklayan ve yerden 1 m. yükseklikten ölçülen gövde çevresi esas alınarak belirlenen değer (tablo 4),
- Sağlık indisi: Ağacın gövde ve tepe tacı gelişimine göre belirlenen ve 2 ile 8 arasında tanımlanan değer, (8: çok sağlıklı ve gelişimi oldukça güçlü; 6: sağlıklı, gelişimi orta düzeyde, kısmen yaralarm kallus ile örtülenmesi görülebilir; 4: zayıf gelişimli, açık yara oluşumları mevcut; 2: çöküntü evresinde, kovuk oluşumları ve mantar enfeksiyonları belirgin),

- Konum ve estetik değer indisi: 3 kritere göre belirlenen ve 3 ile 8 arasinda değişen değer: 
a- Alle değeri: oldukça dikkat çekici: 4; peyzaj etkisi çok belirgin: 3; peyzaj etkisi belirgin: 2; peyzaj etkisi az belirgin: 1

b- Ağaç dizisi ya da alle oluşumunun homojenliği: homojen: ağaçların \% 80'inden fazlası mevcut olan; heterojen: ağaçların \% 80'inden azı mevcut olan c- Miras değeri: alle oluşumu özel koruma değeri taşıyan: 2; alle oluşumu özel koruma değeri taşımayan: 1

olarak değerlendirilmektedir.

Aşağıdaki örnek hesaplama yöntemini anlamayı kolaylaştıracaktır:

$143 \mathrm{~cm}$ çevre ölçüsüne sahip, iyi durumda, sağlıklı, homojen bir allenin bireyi olan, özel koruma değeri taşımayan, peyzaj etkisi oldukça belirgin bir çınar ağacı için:

Konfor ya da finansal değeri=

a- Takson değeri: $10 / 12 \mathrm{~cm}, 25 \mathrm{EU}=2,5$

b- Boyut indisi: $143 \mathrm{~cm}, 15$

c- Sağlık indisi: Sağlıklı, 8,

d- Konum ve estetik değeri:

- peyzaj etkisi çok belirgin: 3 ,

- homojen alle bireyi: 2 ,

- miras değeri: Özel koruma önemi yok;1

İndis $=3+2+1=6$
Finansal ya da konfor değeri $=2,5 \times 15 \mathrm{X}$ $\mathrm{x} 8 \times 6=1800 \mathrm{EU}$

olarak belirlenir.

Ağaçların değerinin ortaya konulmasında en yaygın kullanıma sahip olan yöntemlerden biri, "Ağaç ve Ağaçlıkların Süs Değeri” olarak ta tanımlanan, uygulanması oldukça basit ve kullanışlı Helliwell yöntemidir (Coombs 1994). Bu yöntem genel olarak grup, alle ve soliter halde bulunan ağaçlara uygulanmakta ve büyüklük (kaplama yüzeyi), peyzajdaki önemi ve konumu, beklenen ömrü, diğer ağaçların mevcudiyeti, çevresel ilişkileri, form, ve özel faktörler olmak üzere 7 adet ölçüte göre değerlendirilmektedir.

Her ölçüt için incelenen ağacin özelliklerine göre 0 ile 4 arasında değişen $(0,0,5,1,2,3,4)$ indis ya da katsayılar atanmakta (Tablo 5) ve belirlenen birim fiyat (2000 yılında revize edilmiş birim fiyat: 14 £) ile çarpılmaktadır (Watson 2002):

Ağaç değeri= büyüklük (kaplama yüzeyi) $\mathrm{x}$ peyzajdaki önemi ve konumu $\mathrm{x}$ beklenen ömrü $x$ diğer ağaçların mevcudiyeti x çevresel ilişkileri $\mathrm{x}$ form $\mathrm{x}$ özel faktörler) x £14

Tablo 5. Ağaç ve ağaçlıkların süs değerinin saptanmasında ölçütler ve katsayılar (Coombs 1994)

\begin{tabular}{|c|c|c|c|c|c|c|}
\hline & \multicolumn{6}{|c|}{ Katsayılar } \\
\hline Ölçütler & 0 & 0.5 & 1 & 2 & 3 & 4 \\
\hline $\begin{array}{c}\text { Büyüulkükk } \\
\text { (Kaplama alanı) }\end{array}$ & - & $\begin{array}{l}\text { çok küçük } \\
2-5 \mathrm{~m} 2\end{array}$ & $\begin{array}{c}\text { küçüuk } \\
5-10 \\
\text { m2 }\end{array}$ & $\begin{array}{c}\text { orta } \\
25-50 \mathrm{~m} 2\end{array}$ & $\begin{array}{c}\text { büyük } \\
100-150 \mathrm{~m} 2\end{array}$ & $\begin{array}{c}\text { çok büyük } \\
>200 \mathrm{~m} 2\end{array}$ \\
\hline Beklenen ömür & & & $2-5$ yaş & $5-40$ yaş & $40-100$ yaş & $>100$ yaş \\
\hline $\begin{array}{l}\text { Peyzajdaki önemi } \\
\text { ve konumu }\end{array}$ & yok & çok az & $\mathrm{az}$ & biraz & $\begin{array}{l}\text { kabul } \\
\text { edilebilir }\end{array}$ & çok \\
\hline $\begin{array}{c}\text { Diğer ağaçların } \\
\text { mevcudiyeti }\end{array}$ & & ağaçlık & birçok & biraz & $\mathrm{az}$ & yok \\
\hline Çevresel ilişkileri & $\begin{array}{l}\text { tümüyle } \\
\text { uygunsuz }\end{array}$ & $\begin{array}{c}\text { az } \\
\text { uygunsuz }\end{array}$ & $\begin{array}{c}\text { kismen } \\
\text { uygun }\end{array}$ & $\begin{array}{l}\text { belirgin } \\
\text { uygun }\end{array}$ & çok uygun & $\begin{array}{c}\text { oldukça } \\
\text { uygun }\end{array}$ \\
\hline Form & - & kötü & zayıf & orta & iyi & çok iyi \\
\hline Özel faktörler & - & - & yok & 1 & 2 & 3 \\
\hline
\end{tabular}




\section{DEĞERLENDİRME ve SONUÇ}

Günümüzde ülkelere ve farklı yaklaşımlara göre geliştirilmiş olan çok sayıda ağaç değerlendirme yöntemi kullanılmaktadır. Özellikle belirtmek gerekir ki, reel değeri ortaya koymaya yönelik tüm yöntemlerde esas alınan ölçütler gözlemlere dayalı olup soyut niteliklidir. Dolayısı ile yöntemler kadar, aynı yönteme göre değerlendirme yapan kişi ya da uzmanlara göre de farklılıklar çıkması söz konusudur.

Nitekim A.B.D.'nde, 5 farklı ülkede uygulanan 5 ayrı değerlendirme yöntemi (CTLA-ABD; STEM-Yeni Zellanda,
Helliwell-Büyük Britanya, Norma Granada-İspanya, Burnley-Avustralya), 9 uzman tarafindan 6 farklı türe mensup olan aynı ağaçlar üzerinde uygulanmış ve elde edilen sonuçları karşılaştırılmıştır. Elde edilen bulgularda gerek yöntemler gerekse değerlendirme yapan uzmanlar arasında farklılıklar saptanmıştır. Değerlendirmelerde CTLA ve Helliwell yöntemleri istisnasız hep en düşük, Norma Granada yöntemi de genellikle en yüksek değerleri vermiştir. Helliwell yöntemi sonuçlarında uzmanlar arasında önemli düzeyde farklılıklar ortaya çıkarken, STEM yöntemi sonuçlarında bu farklılık oldukça düşük kalmıştır (Tablo 6) (Watson 2002).

Tablo: 6. Farklı yönteme göre hesaplanan 6 değişik türe mensup ağaçların \$ cinsinden değerleri (Watson 2002)

\begin{tabular}{|l|l|l|l|l|l|l|}
\hline $\begin{array}{c}\text { Değerlendirme } \\
\text { Yöntemi }\end{array}$ & $\begin{array}{c}\text { Quercus } \\
\text { palustris }\end{array}$ & \multicolumn{1}{|c|}{$\begin{array}{c}\text { Ulmus } \\
\text { americana }\end{array}$} & \multicolumn{1}{|c|}{ Tilia sp } & \multicolumn{1}{|c|}{$\begin{array}{c}\text { Gymnocladus } \\
\text { dioica }\end{array}$} & $\begin{array}{c}\text { Fagus } \\
\text { sylvatica }\end{array}$ & $\begin{array}{c}\text { Fraxinus } \\
\text { excelsior }\end{array}$ \\
\hline CTLA & $10700 \mathrm{a}$ & $2000 \mathrm{a}$ & $17300 \mathrm{~b}$ & $600 \mathrm{a}$ & $13900 \mathrm{a}$ & $5700 \mathrm{a}$ \\
\hline Helliwell & $5313 \mathrm{a}$ & $2361 \mathrm{a}$ & $3985 \mathrm{a}$ & $2361 \mathrm{~b}$ & $25190 \mathrm{~b}$ & $4723 \mathrm{a}$ \\
\hline STEM & $46485 \mathrm{~b}$ & $37812 \mathrm{~b}$ & $48402 \mathrm{c}$ & $37600 \mathrm{~d}$ & $60461 \mathrm{c}$ & $42822 \mathrm{~b}$ \\
\hline Burnley & $78898 \mathrm{~b}$ & $26096 \mathrm{~b}$ & $64994 \mathrm{c}$ & $4460 \mathrm{c}$ & $122950 \mathrm{~d}$ & $46661 \mathrm{~b}$ \\
\hline Norma Granada & $59935 \mathrm{~b}$ & $40360 \mathrm{~b}$ & $\begin{array}{l}109 \\
928 \mathrm{~d}\end{array}$ & $3322 \mathrm{~b}$ & $167212 \mathrm{e}$ & $87068 \mathrm{c}$ \\
\hline
\end{tabular}

Not: a- en düşük değeri temsil etmektedir.

Bu sonuçlar ağaç değerinin saptanmasında gerek değerlendirme yöntemlerine ve ölçütlerine, gerekse bu ölçütleri uygulayan uzmanlara göre önemli farklılıklar olduğunu ortaya koymaktadır. Bu nedenle hesaplama yöntemlerinde yeni arayışlar devam etmektedir. Diğer yandan ülkemizde ağaçların korunması ve değerlendirilmesinde sahip olunan akademik bilgi kadar bu bilginin belediyelerdeki karar vericiler tarafindan değerlendirilmesi ve uygulamaya dönük olarak kullanılması için farkındalıkları artırıcı daha fazla çalışmalara ihtiyaç duyulmaktadır. Ağaçların "kentsel ölçekte ve topluca değerlendirildiğinde", kentsel ortamların ekonomik değer açısından önemli bir bileşeni olduğu da çeşitli araştırmalarla ortaya konmuştur (Faast ve Cooling 2010), (Tablo 7).

Gerçekte kent ağaçlarının reel ekonomik değerleri oldukça yüksek düzeylerdedir ve bu durum yeterince bilinmemektedir. Diğer bir araştırmada CTLA yöntemi ile A.B.D.'nin 8 eyaletinde yapilan hesaplamada ortalama değerler olarak; New York 5.189, Atlanta 3.710, Baltimore 3.365, Philadelphia 1.751, Boston 1.253, Oakland 757, Syracuse 525 ve Jersey City eyaletinin 101 milyon \$ düzeyinde ağaç varlığına sahip olduğu belirlenmiştir. Ayrıca aynı yaklaşımla ülke genelindeki 48 eyalette bulunan kent ormanlarındaki tüm ağaçların toplam değerinin de 2.4 trilyon \$ olduğu hesaplanmıştır (Nowak ve ark. 2002). 
Tablo 7. Bir Avustralya kentinde yetişen 100000 büyük olgun kent ağacı için çeşitli çevresel ekonomik değerlerin tahmini (Avustralya \$) (Moore 2009'dan değiştirilmiştir)

\begin{tabular}{|c|c|c|c|c|}
\hline Parametre & Her bir ağaç için değer & Miktar & Birim Fiyat & $\begin{array}{l}\text { Toplam } \\
\text { değer }\end{array}$ \\
\hline Karbon depolama & 12.5 ton & $\begin{array}{l}1.25 \text { milyon } \\
\text { ton }\end{array}$ & Ton başına $\$ 20$ & 25 milyon \$ \\
\hline Yol ağacı değeri & $172 \$ / y 1 l$ & & & $\begin{array}{l}20 \text { milyon } \\
\$ / y 11\end{array}$ \\
\hline Elektrik tasarrufu & $30 \mathrm{kWh}$ & $\begin{array}{l}3 \text { milyon } \\
\mathrm{kWh}\end{array}$ & her bir $\mathrm{kWh} 0.17 \$$ & $510,000 \$ / \mathrm{y} 1 \mathrm{l}$ \\
\hline $\begin{array}{l}\text { Birktirilen } \\
\text { emisyonu }\end{array}$ & Her bir kWh $1.2 \mathrm{~kg}$ & 3,600 ton & Her tonu $20 \$$ & $72,000 \$ / y 11$ \\
\hline $\begin{array}{l}\text { Elektrik üretiminden su } \\
\text { tasarrufu }\end{array}$ & $\begin{array}{l}100 \mathrm{~L} \text { her bir kWh'da } \\
\text { ağaç başı } 30 \mathrm{kWh}\end{array}$ & $\begin{array}{l}300 \text { milyon } \\
\text { L }\end{array}$ & kLbaşı $1.50 \$$ & $45,000 \$$ \\
\hline Asfalt ömrünü uzatma & $\begin{array}{l}20 \text { yıl ömür için m2 } \\
\text { başına } 450 \$\end{array}$ & & $\begin{array}{l}\mathrm{m} 2 \text { başına } 225 \$ \text { (10 yıl } \\
\text { ömrü uzatma) }\end{array}$ & $47,250,000 \$$ \\
\hline
\end{tabular}

Council of Tree and Landscape Appraisers'in verilerine göre olgun bir ağacin reel değeri 1000 \$ ile 10000 \$ arasında değişebilmektedir (Anonim, 2014). Ülkemizde nüfus artışı ve kentleşme, yeşil alanların üzerindeki rant baskısını artırmakta ve yeşil alanlarımızdaki ağaçlar gerektiği gibi korunamamaktadır. Kentlerimizde mevcut ağaçlık alanların korunmasında o alanın reel değerinin bilinmesi de ayrıca önem taşımaktadır.

Kentlerdeki ağaçların mevcut durumlarının detaylı bir şekilde belirlenmesi, izlenmesi, bakımı ve yönetimi günümüz kentlerinin oldukça önemli yönetim konularından biridir. Başta Belediyeler olmak üzere kent yöneticileri veya karar vericilerine çok amaçlı kentsel karar verme, politika oluşturma, durum belirleme ve projelendirme işlemlerine altlık oluşturma, kent ağaçlarının ağaç bakımı, dikimi, kaldırılması ve korunması gibi çok yönlü çalışmalarda ağaçların koruma ve reel değerinin saptanması gerekmektedir. Kentlerimizin olması gereken düzeyde ağaç varlığına kavuşturulması ve bunun sağlıklı bir şekilde devam ettirilmesi, mevcut varlığın ortaya konularak, eksiklerin belirlenmesi ile mümkün olabilecektir. Ülkemiz kentlerinin ağaç varlığı konusundaki yeterlilikleri, gelişmiş ülkelerin ağaç varlığı ile karşılaştırılarak içinde bulunduğumuz durum ortaya konulmalı ve iyileştirme konusunda gerekli plan ve uygulamalar yapılmalıdır.

\section{KAYNAKLAR}

Albian N, Berwıck C (2004) Forêt et religion au Japon: d'une vision singulière de l'arbre à une gestion particulière de la forêt. Revue Forestière Française 56(6):563-572

Anonim (2014) Council of Tree and Landscape Appraisers, Erişim tarihi.30 Haziran 2014

Arbour D (2005) Étude qualitative des arbres et des boisés et des impacts du projet. Rapport d'étude. Centre Universitaire de Santé Mc Gill. Luc Nadeau, Ingénieur Forestier Experts-Conseils, $14 \mathrm{p}$

Bonnardot A, Riboulet C (2004) Evaluer la valeur financiere des arbres d'ornement et estimer le montant des indemnités en cas de dommages. Arbre en questions. Fiche Conseils de l'Arboriculture Ornementale. Societé Française d'Arboricultere, 3 p.

Bourgery C, Bonnardot A (2002) La gestion: Évaluer la valeur financière des arbres d'ornement \& estimer le montant des indémnités en cas de dommages. (Document issu de la charte de l'arbre de Seine et Marne signée le 18 juin 1994 par les Présidents du C.G.S, et C.S.T.P. et C.A.U.E. de Seine et Marne et par les Directeurs de la D.D.E., E.F., G.F. et F.T.de Seine et Marne) 102 p. Novembre 2002. pp. 85 - 92. 
City of Portland Bureau of Planning (1999) Tree preservation and planting. City council adopted report and recommendation, July, 1999. City and Neighborhood Planning Portland Bureau of Planning 1120 SW Fifth Avenue, Room 1002 Portland, Oregon 97204 - 1966. 72 p

Communauté Urbane de Lyon (2001) Disposition relatives a la protection des arbres communautaires. Reglement de voire. Fixant les modalités administratives et techniques applicables aux travaux excécutés sur le domaine public communautaire (Delibération du Conseil du communauté du 22 janvier 2001). Communaute Urbaine de Lyon, DGSUP - DV - 20, Rue du Lac. BP 3103, 69399 Lyon Cedex $03.25 \mathrm{p}$

Coombs SA (1994) Amenity valuation: The Helliwell system revised. Arboricultural Journal 18:137-148

Cormier C (2008) Étude qualitative et quantitative des arbres. Rapport d'étude. Square Dorchester et Place du Canada. Luc Nadeau, Ingénieur Forestier Experts-Conseils, $8 \mathrm{p}$

Crews J (2003) Le symbolisme de la forêt et des arbres dans le folklore. Perception des forêts. Unasylva, 213(54):37 - 43

Cullen S (2005) Tree appraisal: Chronology of north american industry guidances. Journal of Arboriculture, vol.31, no:4, pp. 157 - 162

Çolak AH (2001) Ormanda Doğa Koruma (Kavramlar - Prensipler - Stratejiler Önlemler). Milli Parklar ve Av - Yaban Hayatı Genel Müdürlüğü Yayını, ISBN: 975 - 8273 - 7, Ankara

Dirik H (2008) Bitkilendirme ve Dikim Teknikleri (Planting and Plantation Technics). İstanbul Üniversitesi Orman Fakültesi Yayınları No: 4729/490, ISBN: 975-404-800-1, 542 p

Dirik H (2014) Arborikültür (Kentsel Ağaç Kültürü) (Ornamental Arboriculture). İstanbul Üniversitesi Orman Fakültesi Yayınları, 566 p. (Basım aşamasındadır)

Dirik H, Ata C (2005) Kent ormancılığının kapsamı, yararları, planlanması ve teknik esasları. İ.Ü. Orman Fakültesi Dergisi, 55(1): 1 - 14

Faast R, Coolıng F (2010) Independent inquiry into management of trees on public land. GPO box 2693, Adelaide SA 5001 december 2010, Ecological Associates Reportno: el001-3-f, 150p

Forrest M (2006) Landscape trees and shrubs. Selection, use and management. CABI Head Office Nosworthy Way, Wallingford Oxon OX10 8DE,UK. ISBN: 13 - 978 - 1 - 84593 $054-7,179 p$

Garcia C, Pascal J-P, Kusgalappa, CG (2006) Les forêts sacrées du Kodagu en Inde: Écologie et religion. Bois et Forêts des Tropiques 288: 5 13
Harris RW, Clark, J R, Nelda, PM (2004) Arboriculture. integrated management of landscape trees, shruubs, and wines. Fourth Edition, Prentice Hall, Upper Saddle River, New Jersey 07458, ISBN: 0 - 13 - 08882 - 6, 580 $\mathrm{p}$

Hartman JR, Pirone T P, Sall MA (2000) Pirone's Tree Maintenance. Seventh Edition, Oxford Universty Press, Oxford - New York, ISBN: 0 19 - $511991-6,545 \mathrm{p}$

Konıjnendijk C, Sayaka S, Randrup TB, Schıpperıjn $\mathrm{J}$ (2004) Urban and peri - urban forestry in a development contex - strategy and implementation. Journal of Arboriculture, vol.30, no:5, pp. 269 - 276

Krulic B (2004) La fôret. Autrement Série Mutations, no:22, 1 p.

Kuchelmeister G (2000) Des arbres pour millénaire urbain: Le point sur le foresterie urbaine. Arbres hors forêts. Unasylva, vol. 51, no: 200, pp. 49 55.

Lamontagne J (2008) L'arbre et l'équilibre urbain. Chronique arboricole, Progrès Forestier, février, pp. $4-6$.

Moore, GM (2006) Urban tree valuation - a current perspective and progress report. The 7 th National Street Tree Symposium 2006, 4 p.

Musselman LJ (2003) Les arbres dans le Coran et la Bible. Perception des forêts Unasylva, 213(54):45 52

Nowak D.J, Crane D.,E, Dwyer JF (2002) Compensatory values of urban trees in the United States. Journal of Arboriculture, 28(4): 194 - 199

Pardo C (2005) Du rural à l'urbain. Intégrations, usages et gestions de l'arbre dans les paysages de la méditerranée nord-occidentale. Thèse presentée à l'Université Paul Valery - Montpellier III Arts et Lettres, Langues et Sciences Humaines et Sociales UFR III. Département de Géographie et d'Aménagement pour obtenir le grade de docteur spécialité: Géographie, Soutenue le: Décembre 2005., $606 \mathrm{p}$

Russel T, Culter C (2008) L'Encyclopédie Mondiale des Arbres. Une Guide Superbement Ilustré sur les Arbres du Monde. Hachette Pratique. ISBN: 978 $2-0123$ - 5899 - 7, Paris, 256 p.

Sène EH (2003) Arbres, forêts, croyances et religions en Afrique de l'Ouest Sahélienne. Perceptions des forêts. Unasylva 54(213):44

Swamy PS, Kumar M, Sundarapandian SM (2003) Spirtualité et écologie des bois sacrés au Tamil Nadu, Inde. Perception des forêts. Unasylva, 54(213): 53 - 58.

Tez Z (2008) Biyolojinin Kültürel Tarihi. Doruk Yayınları ISBN: 978 - 975 - 553 - 487 - 9, İstanbul

USDA (2005) Trees in the city: measuring and valuing the urban forest. Forest science review., no 3, $6 \mathrm{p}$ 
Watson G (2002) Comparing formula methods of tree appraisal. Journal of Arboriculture 28(1): 11 - 18

Westphal L M (2003) Social aspects of urban forestry urban greening and social benefits: a study of empowerment outcomes. Journal of Arboriculture 29(3): $137-147$.

Vergriete Y, Labrecque M (2007) Rôles des arbres et des plantes grimpantes en milieu urbain: Revue de littérature et tentative d'extrapolation au contexte montréalais. Rapport d'étape destiné au Conseil Régional de l'Environnement Montréal. 36 p.

World Forestry Center, Morgan R (2005) A Technical guide to urban and community forestry in Washington, Oregon and California (Şehir Ormancılığı Rehberi Çeviren: Dr. Hidayet Karakurt). İzmir Büyükşsehir Belediyesi, IZSU Genel Müdürlüğü, Eğitim Müdürlüğü Yayını, İzmir. 